\title{
Evaluation of the Apically Extruded Debris Associated With the Use of Different Single-File Systems
}

\section{Farklı Tek Eğe Sistemlerinin Kullanımına Bağıl Olarak Apikalden Taşan Debrisin Değerlendirilmesi}

\author{
Özgür Genç Şen ${ }^{1 *}$ and Esin Özlek ${ }^{2}$ \\ ${ }^{1}$ Department of Endodontics, Faculty of Dentistry, V an Yuzuncu Yil University, Van, Turkey \\ 2 Private Dentist, Istanbul, Turkey
}

\begin{abstract}
Objective: Debris extrusion during root canal preparation may cause various post-operative complications. The aim of this study was to compare the amount of debris extruded apically associated with the use of different single-file systems during root canal preparation.

Materials and Methods: Seventy-five mandibular premolar teeth were randomly divided into 5 groups of 15 teeth each. Group 1, OneShape; group 2, WaveOne; group 3, OneFile with reciprocating motion; group 4, OneFile with rotational motion; and group 5, Reciproc. Irrigant and debris extruded during instrumentation were collected in pre-weighed Eppendorf tubes. In order to determine the dry weight of the extruded debris, tubes were stored in an incubator at $68^{\circ} \mathrm{C}$ for 5 days then weighed again. Initial weights of the tubes were subtracted from last weights. Data were statistically evaluated via the Kruskal-Wallis test.
\end{abstract}

Results: There were no statistically significant differences between the amounts of apically extruded debris in any of the groups $(p>0.05)$.

Conclusion: In this study, all the single-file systems used resulted in some debris extrusion. The OneShape file was associated with the least debris extrusion.

Key Words: Root canal preparation, instruments, apical, periapical tissue

\section{Introduction}

Dentinal chips, pulpal fragments, necrotic debris, irrigation solutions and microorganisms can be pushed out of the apical foramen into periapical tissues during chemomechanical preparation. The extrusion of these materials into periapical tissues may cause inflammation and postoperative pain,

\section{ÖZET}

Amaç: Kök kanal preparasyonu esnasında apikalden debris taşması çeşitli post-operatif komplikasyonlara yol açmaktadır. $\mathrm{Bu}$ çalışmanın amacı farklı tek eğe sistemlerinin kök kanal preparasyonunda kullanımı esnasında apikalden taşan debris miktarlarının değerlendirilmesidir.

Gereç ve Yöntemler: Yetmiş beş adet alt küçükazı dişi her grupta 15 diş olacak şekilde rastgele 5 gruba ayrıldı. 1 . Grup: OneShape; 2. Grup: WaveOne; 3. Grup: OneFile rotasyonel hareketle; 4. Grup: OneFile resiprokal hareketle; 5. Grup: Reciproc. Şekillendirme işlemi esnasında apikalden taşan debris ve yıkama solusyonu daha önceden tartılmış olan Eppendorf tüplerinde biriktirildi. Kuru debrisin ağırlığını belirlemek için tüpler inkübatör içerisinde $68^{\circ} \mathrm{C}$ de 5 gün bekletildi ve yeniden tartıldı. Son ağırlıklar tüplerin ilk ağırlıklarından çıkarıldı. Elde edilen Veriler istatistiksel olarak Kruskal-Wallis testiyle değerlendirildi.

Bulgular: Gruplar arasında istatistiksel olarak önemli bir fark bulunamadı $(p>0.05)$.

Sonuç: Bu çalışmada kullanılan tüm tek eğe sistemleri apikalden bir miktar debris taşmasına sebep olmuştur. En az debris OneShape eğesinin kullanıldığı grupta taşmıştır.

Anahtar Kelimeler: Kök kanalını hazırlama, aletler, apikal, apeksi çevreleyen doku

and delay periapical healing (1). Various studies have demonstrated that none of the various techniques and instruments available can clean and shape the root canal system without producing some apically extruded debris (2). Nonetheless, studies have shown that different instrumentation techniques are associated with varying degrees of extrusion of debris, with some 
extruding more material than others (3-5). As apically extruded debris generates an acute inflammatory reaction in the periapical tissues, it forms a suitable parameter for assessing the efficacy of instrument designs and instrumentation techniques during the preparation of root canals (6).

Previous studies have compared the debris extruded apically when using Reciproc (VDW, Munich, Germany), WaveOne (Dentsply Maillefer, Ballaigues, Switzerland) and OneShape (Micromega, Besancon, France) files, (7-9) but to the best of our knowledge, no research has been published on the OneFile (Global Top Inc., Gyeonggi-do, Korea) instrument in this respect. The production of the OneFile single-file utilises a new nano-coating technology, it has a convex triangular design, and it is available in different sizes $(21.08,25.08,40.08)$. The recommended rotational settings are $250-450 \mathrm{rpm}$ and $2.5 \mathrm{Ncm}$ torque, and the manufacturers claim that it can also be used with the same reciprocating settings recommended for the WaveOne and Reciproc systems. This study aimed to compare the amounts of debris extruded apically associated with the use of the OneFile, OneShape (with reciprocating or rotational motion), WaveOne and Reciproc single-file systems.

\section{Methods}

This study was approved by clinical ethics committee of Yuzuncu Yil University.

Selection of Teeth: Seventy-five intact singlerooted inferior premolar teeth with mature apices and straight root canals $\left(<10^{\circ}\right)$ were selected. The degree of curvature was calculated via the method described in Schneider (10). The external root surfaces were cleaned of calculus and soft tissue remnants with a periodontal curette. In order to verify the presence of a single canal anatomy, bucco-lingual and mesio-distal radiographs were taken. The root apices were viewed under a stereomicroscope at $25 \mathrm{x}$ magnification (SZ-PT Olympus, Tokyo, Japan), and only teeth with a single apical foramen were included. The teeth were decoronated to obtain approximately $14-\mathrm{mm}$ long root segments. The pulpal remnants were extirpated using a barbed broach (Dentsply Maillefer, Tulsa, OK, USA). A \#10 K-file (Dentsply Maillefer, Tulsa, OK, USA) was inserted into the root canal until its tip was visible at the apical foramen. The working length utilised was 1 $\mathrm{mm}$ short of this length. All external root surfaces were covered with two layers of nail polish, except
$1 \mathrm{~mm}$ around the apical foramen. The teeth were randomly divided into 5 groups $(\mathrm{n}=15$ per group).

Collection Apparatus: An experimental model described previously (11) was used to collect extruded debris and irrigant. Empty eppendorf tubes were weighed three times using an analytical balance (Sartorius Basic, Sartorius AG, Gottingen, Germany) with an accuracy of $10^{-4} \mathrm{~g}$, and the mean initial weight of each tube was calculated based on these measurements. Each tube was placed in a glass bottle. A heated metal skewer was used to make a hole in the centre of the cap of the Eppendorf tube, to fix the root. A 25-G dental needle was inserted into the plastic cap to equalize the internal and external pressure. Then, each cap with the root and the needle was attached an Eppendorf tube with cyanoacrylate adhesive. Tubes were placed in glass bottles wrapped in aluminium foil to prevent the operator from being able to see the root apex during instrumentation. The apparatus used for the collection of extruded debris and irrigant is shown in Figure 1.

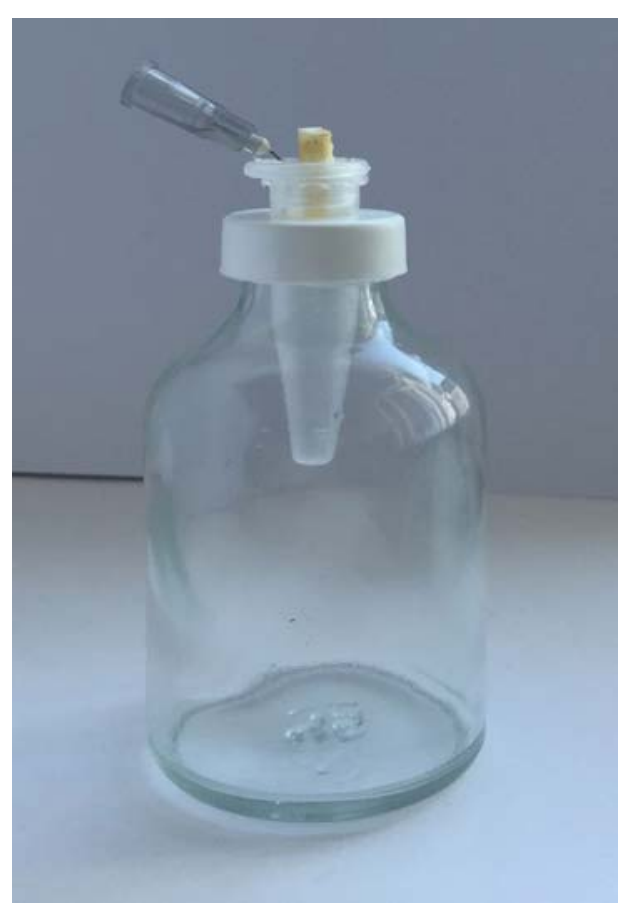

Fig. 1. The apparatus used for the collection of extruded debris.

Root Canal Instrumentation: Before instrumentation, a glide path was created by inserting a \#15 stainless steel K-file (Dentsply Maillefer, Ballaigues, Switzerland) up to the working length. The roots were randomly divided into 5 experimental groups according to the file system as follows: 
Group 1: Root canals were instrumented using a OneShape file (size 25, taper 0.06) with an inand-out action at a rotational speed of $400 \mathrm{rpm}$ and $2 \mathrm{Ncm}$ torque in conjunction with an X-Smart Plus endomotor (Dentsply Maillefer, Ballaigues, Switzerland).

Group 2: Root canals were instrumented with a WaveOne-Primary file (size 25, taper 0.08) using the recorded WaveOne program of the X-Smart Plus endomotor.

Group 3: Root canals were instrumented with an OneFile instrument (size 25, taper 0.08) using the recorded Reciproc program of the X-Smart Plus endomotor, in accordance with the manufacturer's instructions.

Group 4: Root canals were instrumented with a OneFile instrument (size 25, taper 0.08) at a rotational speed of $350 \mathrm{rpm}$ and $2.5 \mathrm{Ncm}$ torque using the X-Smart Plus endomotor in accordance with the manufacturer's instructions.

Group 5: Root canals were instrumented with a Reciproc-R25 (size 25, 0.08 taper) file using the recorded Reciproc program of the X-Smart Plus endomotor.

The same researcher performed all the root canal instrumentation procedures. The flutes of the instruments were cleaned after every 2 in-and-out movements. During instrumentation, each root canal was irrigated using a total of $8 \mathrm{~mL}$ bidistilled water. The preparation was deemed to be complete when the file easily reached the working length. The teeth and tubes were removed from the apparatus after the instrumentation was completed. Debris adhering to the root surface was collected by washing $1 \mathrm{~mL}$ of bidistilled water over the apex, into the eppendorf tube. The tubes were stored in an incubator at $68^{\circ} \mathrm{C}$ for 5 days, to evaporate moisture. A second examiner blinded to the groups weighed each tube three times using the same electronic balance previously used to determine the initial weights of the tubes. The amounts of dry debris were calculated by subtracting the initial weight of the tube from the final weight. Statistical tests were performed using SPSS (version 9.0, SPSS Inc., Chicago, Ill, USA). Data were analysed using the Kruskal-Wallis nonparametric test, and $p<0.05$ was deemed to indicate statistical significance.

\section{Results}

All the single-file systems investigated resulted in measurable extrusion of debris, and there were no statistically significant differences in the amounts of debris extruded in each group ( $p>0.05$ ). The relative amounts of apically extruded debris were as follows: OneShape < OneFile (reciprocating motion) $<$ OneFile (rotational motion) $<$ Reciproc $<$ WaveOne. The means and standard deviations of the weights of extruded debris in each group are shown in Table 1.

Table 1. Mean and standard deviation of apically extruded debris in each group $(\phi>0.05)$. (CR: Continuous Rotation, RM: Reciprocational Movement)

\begin{tabular}{lccc}
\hline Groups & Total $(n)$ & Mean $(\mathrm{mg})$ & $\mathrm{SD}$ \\
\hline OneShape (CR) & 15 & 0.029 & 0.005 \\
WaveOne (RM) & 15 & 0.057 & 0.088 \\
OneFile (RM) & 15 & 0.035 & 0.010 \\
OneFile (CR) & 15 & 0.037 & 0.007 \\
Reciproc (RM) & 15 & 0.041 & 0.011 \\
\hline
\end{tabular}

\section{Discussion}

Chemomechanical procedures during root canal preparation may trigger an inflammatory reaction by pushing dentin particles, necrotic pulp tissue and microorganisms from the apical foramen into the periapical region (12). Therefore, reducing the extrusion of debris can minimize the risk of endodontic flare-up. The aim of this study was to compare the amounts of apically extruded debris caused by root canal shaping with different singlefile systems.

In the current study, single-rooted premolars with straight single canals were used. All tooth lengths were measured and decoronated at a level of 14 $\mathrm{mm}$ from the apex, to ensure standardization. Bidistilled water was used as an irrigant, to prevent any possible weight increase due to crystallization of sodium hypochlorite $(4,7)$. The method described by Myers \& Montgomery (11) was used to collect the apically extruded debris. While the lack of backpressure in the periapical area of the teeth is a limitation of this method, it facilitates the comparison of different instruments under standardized conditions.

All of the single-file systems investigated in the current study caused apical extrusion, and no statistically significant differences were detected between the groups in this respect. The OneShape instrument yielded the least debris extrusion, and the WaveOne and Reciproc instruments yielded the highest. Previous studies have demonstrated that greater apical extrusion can be associated with preparation technique, instrument design and 
differences in instrument taper $(4,7)$. Depending on reciprocating and in-and-out filing motions, the WaveOne and Reciproc files might act as a piston, extruding more debris than the OneShape instrument which operates via continuous rotation (4). The cross-sectional design of the instruments may also have an effect in this respect. The WaveOne instrument has a modified triangular cross-sectional design, and the Reciproc instrument is qualified by an S-shaped crosssection, whereas the OneShape instrument incorporates three different cross-sections along the file. The OneShape's variable cross-sections along the length of the blade may provide more space for better elimination of debris. In the current study, instruments with the same apical sizes were used. The tapers of all instruments were 08, with the exception of the OneShape, which had a taper of 06. The smaller taper of the OneShape file may have had a positive effect on reducing debris extrusion. The larger taper of the WaveOne, Reciproc and OneFile instruments may have resulted in greater debris extrusion than was associated with the OneShape. In an observation concordant with the results of the current study, Topçuoğlu et al (8) reported that the OneShape instrument extruded less debris than both the WaveOne and Reciproc instruments. In that study, the difference was statistically significant.

To the best of our knowledge, no extrusion studies of the instrument named OneFile have been reported to date. The OneFile manufacturers claim that the product can be used with both rotational and reciprocating movements. Therefore, the file was tested in both kinematic contexts in this study. While the use of the OneFile instrument with a reciprocating motion was associated with slightly less debris extrusion than when it was used with a rotational motion, the amounts were almost identical. This result differs from those ascribed to the Reciproc instrument by Arslan et al (13). In that study, they reported that the amount of apically extruded debris associated with the use of that instrument was significantly less when it was used with a reciprocating motion rather than a continuous rotational motion. The different designs of the instruments used may be a reason for this discrepancy.

The results of previously reported investigations of the effects of motion on apical debris extrusion are not consistent. Some studies have reported no statistically significant differences between the amounts of apically extruded debris caused by instruments used with reciprocation and rotation motion, while others have reported significant differences $(7,14,15)$. These discrepancies may be attributable to the different instruments used to compare the effects of movements on debris extrusion in these studies.

All the single-file systems investigated in the current study were associated with some amount of apically extruded debris. While the relatively small differences between them in this respect were not statistically significant, they may be important with regard to reducing the risk of flare-up.

Conflict of interest: Authors declare that they have no conflict of interest.

Acknowledgments: Prof. Dr. Siddık Keskin is gratefully acknowledged for performing the statistical analysis.

\section{References}

1. Seltzer S, Naidorf IJ. Flare-ups in endodontics: I. Etiological factors. J Endod 1985; 11(11): 472478.

2. Gutmann JL, Gao Y. Alteration in the inherent metallic and surface properties of nickel-titanium root canal instruments to enhance performance, durability and safety: a focused review. Int Endod J 2012; 45(2): 113-128.

3. Ferraz CC, Gomes NV, Gomes BP, Zaia AA, Teixeira FB, Souza-Filho FJ. Apical extrusion of debris and irrigants using two hand and three engine-driven instrumentation techniques. Int Endod J 2001; 34(5): 354-358.

4. Bürklein S, Schäfer E. Apically extruded debris with reciprocating single-file and full-sequence rotary instrumentation systems. J Endod 2012; 38(6): 850-852.

5. Silva EJ, Carapiá MF, Lopes RM, Belladonna FG, Senna PM, Souza EM, et al. Comparison of apically extruded debris after large apical preparations by full-sequence rotary and singlefile reciprocating systems. Int Endod J 2016; 49(7): 700-705.

6. De-Deus GA, Nogueira Leal Silva EJ, Moreira EJ, de Almeida Neves A, Belladonna FG, Tameirão M. Assessment of apically extruded debris produced by the self-adjusting file system. J Endod 2014; 40(4): 526-529.

7. Bürklein S, Benten S, Schäfer E. Quantitative evaluation of apically extruded debris with different single-file systems: Reciproc, F360 and OneShape versus Mtwo. Int Endod J 2014; 47(5): 405-409.

8. Topçuoğlu HS, Düzgün S, Akpek F, Topçuoğlu $G$, Akt1 A. Influence of a glide path on apical extrusion of debris during canal preparation using 
single-file systems in curved canals. Int Endod J 2016; 49(6): 599-603.

9. Topçuoğlu HS, Üstün Y, Akpek F, Akt1 A, Topçuoğlu G. Effect of coronal flaring on apical extrusion of debris during root canal instrumentation using single-file systems. Int Endod J 2016; 49(9): 884-889.

10. Schneider SW. A comparison of canal preparations in straight and curved root canals. Oral Surg Oral Med Oral Pathol 1971; 32(2): 271 275.

11. Myers GL, Montgomery S. A comparison of weights of debris extruded apically by conventional filing and Canal Master techniques. J Endod 1991; 17(6): 275-279.

12. Ruiz-Hubard EE, Gutmann JL, Wagner MJ. A quantitative assessment of canal debris forced periapically during root canal instrumentation using two different techniques. J Endod 1987; 13(12): 554-558.

13. Arslan H, Doğanay E, Alsancak M, Çapar ID, Karataş E, Gündüz HA. Comparison of apically extruded debris after root canal instrumentation using Reciproc $(\AA)$ instruments with various kinematics. Int Endod J 2016; 49(3): 307-310.

14. Koçak S, Koçak MM, Sağlam BC, Türker SA, Sağsen B, Er Ö. Apical extrusion of debris using self-adjusting file, reciprocating single-file, and 2 rotary instrumentation systems. J Endod 2013; 39(10): 1278-1280.

15. Üstün $Y$, Çanakçi BC, Dinçer AN, Er O, Düzgün S. Evaluation of apically extruded debris associated with several Ni-Ti systems. Int Endod J 2015; 48(7): 701-704. 